\begin{tabular}{ll}
\hline 臨 & 床 \\
\hline
\end{tabular}

治療開始後も聴力悪化をみた突発性難聴症例

本間 利生・川端五十鈴

\title{
Sudden Deafness with Further Progression of Hearing Loss after Initial Examination
}

\author{
Toshio Homma and Isuzu Kawabata \\ (Saitama Medical Center, Saitama Medical School)
}

This study describes 15 special cases of sudden deafness with further progression of hearing loss after initial examination in our clinic. The authors examined the otological, audiological and laboratory findings of those patients, including family and past history, Results were as follows;

1. The patients consisted of 5 males and 10 females, with an average age of 41 years.

2. Audiological findings with respect to hearing loss were variable.

3. Hearing loss progressed after the initial examination and reached a maximum at about 7 days after the onset of initial hearing loss.

4. Patients could be divided into four groups on the basis of increased hearing loss at various sound frequencies;

(1) increasing hearing loss in the low tone range,

(2) in the middle tone range,

(3) in the low-middle tone range,

(4) in all ranges of tones.

The third group was greatest in number.

5. The progression of hearing loss could be classified into 3 types according to the mode of increasing hearing loss.

Type I hearing loss was characterized by rapid progression after increased hearing loss had begun.

Type II was characterized by slow progression.

Type III was characterized by progression starting after 1 to 3 stable days. These results were discussed from the perspective of clinical audiology.

Key words : sudden deafness, hearing loss progression, slow type

はじめに

突発性難聴といら疾患はその病名で理解されるように 突発性に発生し，短時間の間に高度の難聴を生じる原因 不明の感音性難聴である。そして患者が医療機関を受診 したときは最悪の難聴の状態になっているか，あるいは
すでに最悪の難聴を脱して回復期に向かっているか，の いずれかの状態であって，受診後，さらに難聴が進行す る症例は少ない。しかし突発性難聴と診断された患者の 中で，医療機関を受診し，加療されながらも聴力が悪化 する症例があることが報告されている1) 13)。この病態 
は，突発性難聴の自然経過の結果であるとか，治療に使 用した薬剤の影響，あるいは突発性難聴とは全く別の疾 患を考えるとか，多くの研究報告がみられている．しか し，いずれにおいても突発性難聴の病態を考光る上で， 考慮すべき現象であらら．われわれも，過去 5 年間に拉 ける, このよらな症例を検討し, 若干の考察を加えて報 告する.

\section{対象症例}

1990年12月より1995年11月までの 5 年間に当科で，突 発性難聴之診断され入院加療した症例の中で, 治療開始 後も聴力の悪化が聴力検查によって確認された15例を対 象とした。な拈同期間に入院加療した突発性難㯖症例は 210 例であった. 対象症例はいずれも発症後 5 日以内に 受診した新鮮例である。また突発性難聴の診断基準は, 厚生省突発性難聴研究班で定めた診断基準に従った。対 象例は受診後直ちに入院させ, 可能な限り連日聴力検査 を施行し聴力の变化を確認出来た症例である.

聴力悪化の基準としていくつかの条件が挙げられてい るが(柳田 $5^{8)}$, 平出ら ${ }^{10)}$, 立木ら ${ }^{11)}$, 角田ら $\left.{ }^{12)}\right)$ わわ れの難聴進行の基準は， $125 \mathrm{~Hz}$ から $8 \mathrm{kHz}$ の全周波数 のらち, 初診時聴力と比較し, 少なくとも 2 つ以上の周 波数で $15 \mathrm{~dB}$ 以上の聴力間値上昇を認めたもの，また は, 1 周波数で $25 \mathrm{~dB}$ 以上の閾值上昇したものとした.

これらの症例につき, 発症時の状況, 家族歴, 既往歴, めまいなどの随伴症状の有無などについて詳細な問診を 行った. また，悪化時の難聴の自覚の有無についても問 診を行った.ささらに初診後の難聴の変化ならびに予後に ついて検討した. 予後の判定は厚生省特定疾患急性高度 難聴調査研究班による聴力回復判定基準に準じた.

\section{結 果 \\ 1. 対象症例の概要}

対象症例15例の概要を表 1 に示した．性別は男性 5 例, 女性10例で, 女性に多かった. 年齢は20歳から55歳で, 20 歳代 4 例, 30 歳代 2 例, 40 歳代 3 例, 50 歳代 6 例であり, 平均は41歳であったが，50歳代に比較的多くみられた。 特記すべき家族歴を有する症例はみられなかった。既往 歴として卵管疾患の手術 (症例 1 ), 子宮管腫摘出術 (症 例 9$)$ がみられた以外著患はなかった。 合併症として高 血圧症が 1 例 (症例 7 ), 糖尿病合併例は 2 例 (症例 12,13 ) にみられた。耳疾患の既往歴をもつ症例はみられなかっ
たが，1例(症例14)に対側の原因不明の高音部急墜型の 感音性難聴を認めた.

2 . 難聴発症時の概要と初診時所見

難聴発症の直接的誘因になるものはみられなかった。 難聴発症は全例, 突発的であり, 症例の大半は発症の時 刻をも答えられた．難聴発症の前後，あるいは同時に耳 閉感を訴えるものが多く，また耳鳴を伴らものは 7 例で あり，めまい感を訴えるものが 1 例存在した。発症より 当科受診までの日数は発症当日（第 1 病日） 2 例, 第 2 病 日 5 例，第 3 病日 6 例，第 4 病日 1 例，第 5 病日 1 例で あった．な括 4 例は，他院を受診し，聴力検査を施行さ れておりその聴力所見を参考にした．初診時の難聴の聴 力型は高音漸傾型 8 例, 谷型 3 例, 高音障害型 2 例, 山 型 1 例，水平型 1 例であった.

患者は直ちに入院し, 加療を開始するとともに諸検査 を施行した．精密聴力検査ではすべて内耳性難聴の所見 であり，平衡機能検査を行い得た症例でも前庭機能障害 はみられなかった，血液，尿などの臨床検査でも正常範 囲内であった。な敃血清ウイルス検査にて抗体価上昇を 示寸症例は存在しなかった。

3 . 難聴進行の状況

難聴発症後，さらに難聴が進行する周波数をみるため 初診時の聴力と最悪時の聴力を比較検討してみた。

図1-1は低音域での進行が強い症例(症例10)である. 図1-2 は中音域での進行の症例(症例14)である.図 13 は,低中音域にまたがって難聴の進行している症例(症

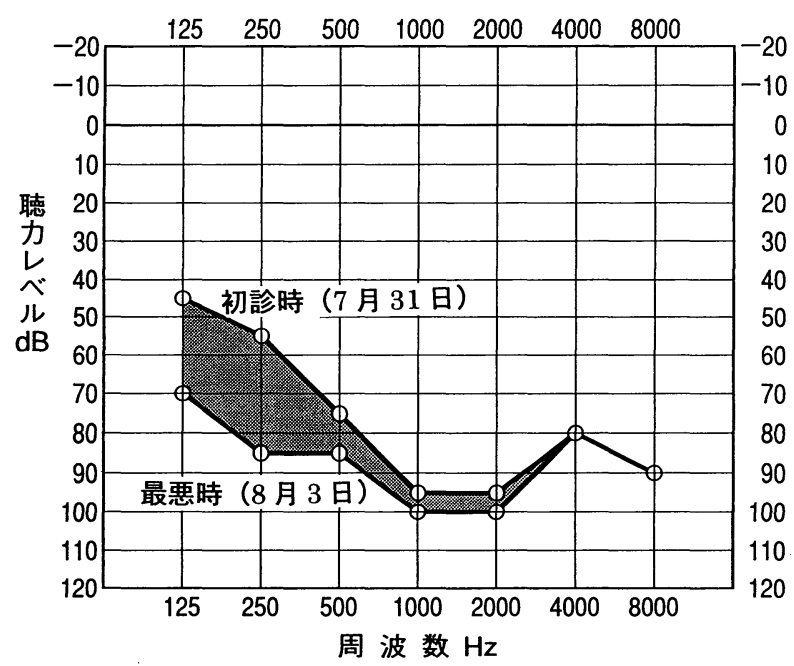

図 1-1 低音域での難聴進行例(症例10) 


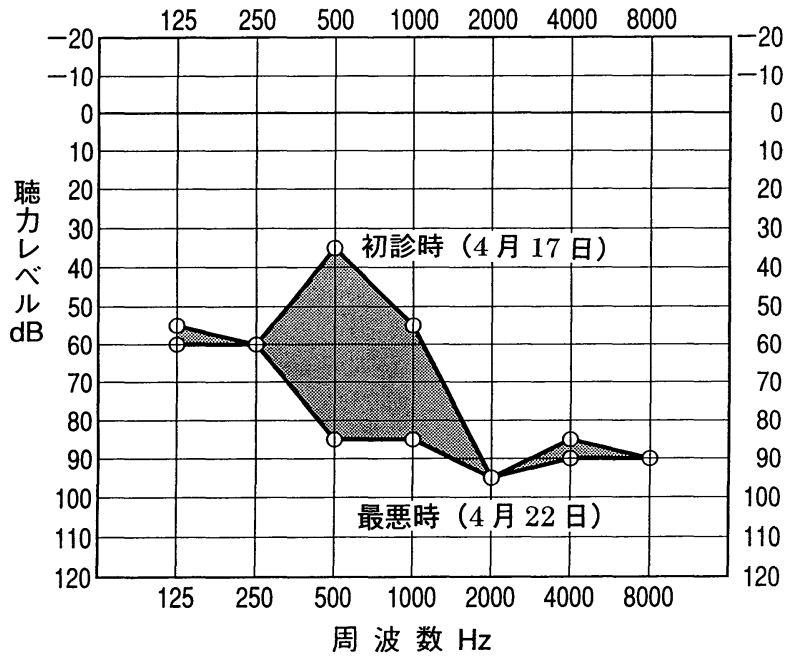

図 1-2 中音域での難聴進行例(症例14)

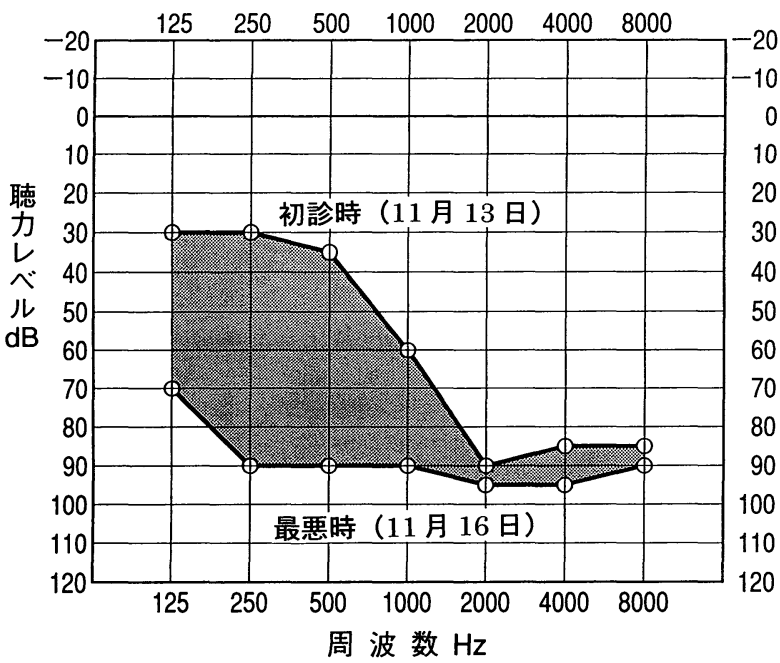

図 1-3 低中音域での難聴進行例 (症例 5 )

例 5 )である.図 1-4 は全周波数域に渡って進行する症 例(症例 9 )である. 以上のように難聴進行を周波数別に 分類してみると, 低音域進行型が 2 例, 中音域進行型 2 例, 低中音域進行型 6 例, 全周波数域進行型 5 例であっ た。

次に難聴発症後の難聴進行の程度を検討した. 前述の 如く難聴進行を周波数別にみると低音域，中音域あるい は, 高音域にまたがっているので, 今回難聴進行の程度 を全周波数の平均値を用い，これを経時的にプロットし 図示した。初診時から最悪の聴力となる時点までの難聴

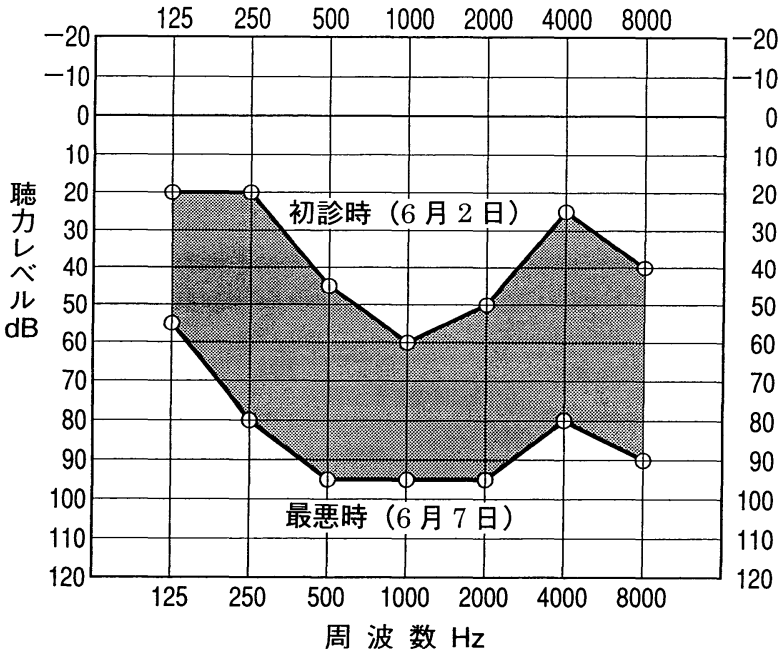

図 1-4 全周波数域での難聴進行例(症例 9)

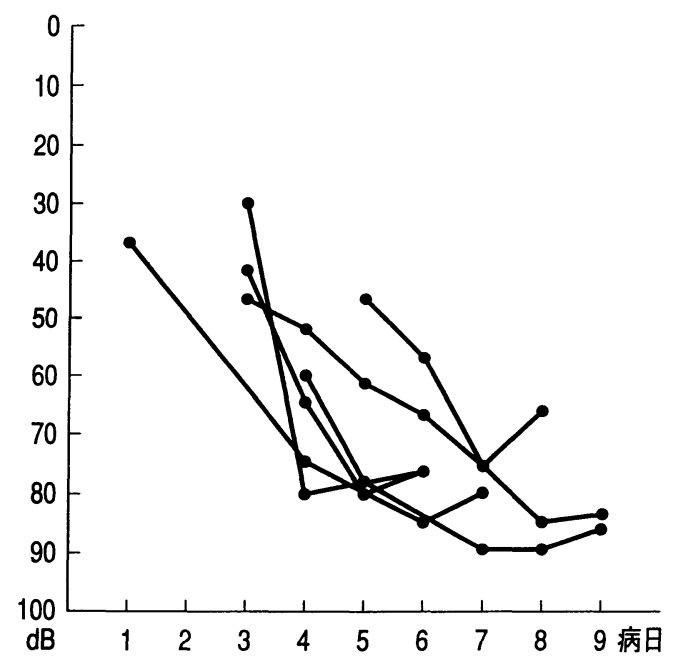

図 2 難聴進行 I 型の 6 例の難聴進行

難聴進行は急速である. 聴力レベル $\mathrm{dB}$ は全周波数の平 均値である。

進行をみると, 進行が急速なものと比較的緩徐なものが みられた。それぞれの進行の様子を図 2 ( 6 症例) と, 図 3 (5 症例)に示し, そして前者を I 型, 後者をII型と分 類した. もら 1 つの進行型として, 初診時と同じ聴力が $2 \sim 3$ 日続いた後に難聴が進行し始めるものであり，こ のよ5な例が 4 例みられたので而型とし, 図 4 に示した.

以上の如く, 難聴の進行には, いくつかのタイプがあ るが難聴発症から進行が停止し最低レベルになるまでの 病日は第 4 病日 1 例, 第 5 病日 1 例, 第 6 病日 7 例, 第 


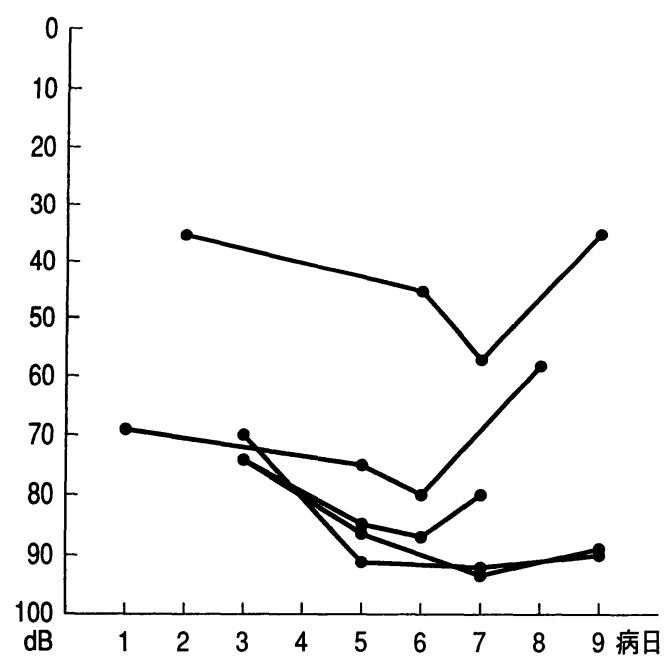

図 3 難聴進行 II 型 5 例の難聴進行

難聴進行は緩徐である. 聴力レベル $\mathrm{dB}$ は全周波数の平 均値である。

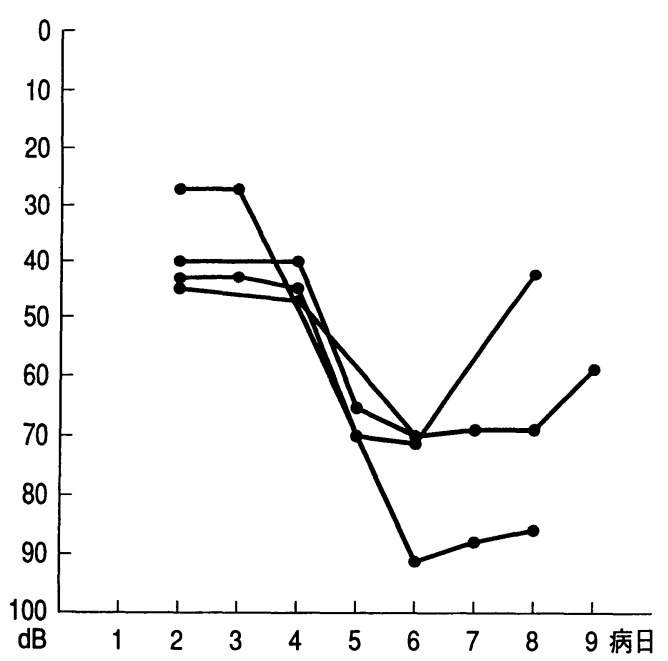

図 4 難聴進行 IIII型 4 例の難聴進行

初診時の難聴が $2 \sim 3$ 日続いた後, 難聴進行が開始する. 聴カレベル $\mathrm{dB}$ は全周波数の平均值である.

表 1 症例一覧

\begin{tabular}{|c|c|c|c|c|c|c|c|c|c|c|c|c|c|c|c|}
\hline \multirow{2}{*}{$\begin{array}{l}\text { 症 } \\
\text { 例 }\end{array}$} & \multirow{2}{*}{$\begin{array}{l}\text { 性 } \\
\text { 別 }\end{array}$} & \multirow{2}{*}{$\begin{array}{l}\text { 年 } \\
\text { 齢 }\end{array}$} & \multirow{2}{*}{$\begin{array}{c}\text { 発症より } \\
\text { 受彭迄の } \\
\text { 日数 }\end{array}$} & \multirow{2}{*}{$\begin{array}{l}\text { 難聴 } \\
\text { 進行の } \\
\text { 自賞 }\end{array}$} & \multirow{2}{*}{$\begin{array}{l}\text { 難聴 } \\
\text { 進行の } \\
\text { 音域 }\end{array}$} & \multirow{2}{*}{$\begin{array}{l}\text { 難聴 } \\
\text { 最悪の } \\
\text { 日数 }\end{array}$} & \multirow{2}{*}{$\begin{array}{l}\text { 難僡 } \\
\text { 進行の } \\
\text { 様 式 }\end{array}$} & \multicolumn{2}{|r|}{ 初誩時 } & \multicolumn{2}{|c|}{ 最悪時 } & \multicolumn{2}{|c|}{ 固定時 } & \multirow[b]{2}{*}{ 予後 } & \multirow[b]{2}{*}{ その他 } \\
\hline & & & & & & & & $\begin{array}{c}\text { 聴力 } \\
\mathrm{dB}\end{array}$ & 聴力型 & $\begin{array}{c}\text { 聴力 } \\
\text { dB }\end{array}$ & 聴力型 & $\begin{array}{c}\text { 聴力 } \\
\mathrm{dB}\end{array}$ & 聴力型 & & \\
\hline 1 & 女 & 52 & 2 & & 中音域 & 7 & II 型 & 35 & 高音漸傾 & 55 & 高音渐傾 & 15 & 正常 & 治瘾 & 卵管疾患 \\
\hline 2 & 男 & 51 & 3 & & 低音域 & 7 & II 型 & 74 & 高音障害？ & 93 & 水平 & 60 & 高音渐傾 & 著明回復 & \\
\hline 3 & 女 & 20: & 3 & 有 & 低中音域 & 5 & I 型 & 41 & 高音漸傾 & 79 & 水平 & 24 & 高音急壁 & 著明回復 & \\
\hline 4 & 女 & 27 & 3 & & 低中音域 & 4 & I 型 & 29 & 高音漸傾 & 80 & 水平？ & 16 & 正常 & 治瘑 & \\
\hline 5 & 女 & 52 & 4 & 有 & 低中音域 & 7 & I 型 & 60 & 高音渐傾 & 88 & 水平 & 40 & 高音漱傾 & 著明回復 & \\
\hline 6 & 女 & 42 & 3 & 有 & 全音域 & 8 & I 型 & 46 & 谷型 & 85 & 水平? & 35 & 谷型 & 著明回復 & \\
\hline 7 & 男 & 43 & 2 & 有 & 全音域 & 6 & III型 & 45 & 谷型？ & 70 & 谷型？ & 70 & 谷型？ & 不変 & 高血压 \\
\hline 8 & 女 & 23 & 5 & & 低中音域 & 7 & I 型 & 46 & 高音障害 & 75 & 高音障害 & 13 & 谷型？ & 治瘑 & \\
\hline 9 & 女 & 52 & 1 & 有 & 全音域 & 6 & I 型 & 37 & 谷型 & 84 & 谷型 & 22 & 谷型 & 著明回復 & 子宮筋腫 \\
\hline 10 & 女 & 20 & 3 & & 低音域 & 6 & II 型 & 76 & 高音漸傾 & 87 & 水平 & 62 & 水平 & 回復 & \\
\hline 11 & 女 & 47 & 2 & 有 & 全音域 & 6 & IIII型 & 43 & 高音漸傾 & 711 & 水平 & 30 & 高音急陻 & 著明回復 & 糖尿病 \\
\hline 12 & 女 & 36 & 2 & 有 & 低中音域 & 6 & III 型 & 40 & 高音漸傾 & 70 & 水平 & 30 & 高音急隥 & 著明回復 & 糖尿病 \\
\hline 13 & 男 & 56 & 3 & & 全音域 & 7 & II 型 & 70 & 水平型 & 92 & 水平 & 47 & 高音渐傾 & 著明回復 & 他側難聴 \\
\hline 14 & 男 & 56 & 1 & & 中音域 & 6 & II 型 & 69 & 山型？ & 84 & 高音障害 & 47 & 高音障害 & 著明回復 & \\
\hline 15 & 男 & 39 & 2 & 有 & 低中音域 & 6 & III型 & 27 & 高音濑傾 & 91 & 水平 & 39 & 高音渐傾 & 著明回復 & \\
\hline
\end{tabular}

7 病日 5 例, 第 8 病日 1 例で, 少なくとも発症後 1 週間 前後には難聴進行は, 停止する様であった.

\section{4. 難聴の予後について}

聴力の治癒判定は厚生省特定疾患急性高度難聴調査研 究班の判定基準に従った. しかし今回は初診時の聴力で はなく, 進行し最低の聴力レベルと回復固定時のそれと の比較で行った. 治瘉 3 例, 回復 1 例, 著明回復 10 例, 不変 1 例であった．低音域，中音域で難聴進行するもの
の予後は比較的良好であったが, 前述の難聴進行程度と 予後との関係は一致しなかった(表 1 ).

\section{考察}

1. 発症後も難聴が進行する突発性難聴

突発性難聴は原因不明の高度の感音難聴で，ある日突 然に発症する疾患である. 診断基準としては難聴の突然 の発症が第 1 に挙げられている. そして発症後, 難聴は 
短時間で最悪の状態となり, 以後は, 改善するか, その まま変化しないかのいずれかの経過をたどり, 難聴がさ らに悪化することはないものと考兄られていた。しかし 近年, 発症後難聴の進行する症例が報告されるようにな った。

1976年寺山ら ${ }^{1)}$ が感冒様症状を伴って発症した突発性 難聴がステロイド投与後, 難聴が進行したと報告した. その後の報告症例を報告年順にみると，1977年柳田ら 2 ) 11例，1981年神崎 ${ }^{344)} 8$ 例, 同11例, 大橋ら 5) 5 例, 1982 年寺山ら6) 9 例, 南7) 4 例, 1983年柳田 ${ }^{8)} 40$ 例, 1986 年寺山ら ${ }^{9)} 29$ 例, 1990 年平出 ${ }^{10)} 15$ 例, 1992 年立木ら ${ }^{11)}$ 9 例, 1993年角田 ${ }^{12)} 10$ 例, 1995 年吉田ら ${ }^{13)} 12$ 例であ る. 同一施設からの報告は症例の重複もあるが，いずれ にしても多くの症例がみられており, 難聴進行の突発性 難聴の存在は確実であろう。その発生頻度を, 突発性難 聴症例の中に占める割合をみると， $32 \%(9 / 28$, 立木 $\left.5^{11)}\right), 18.5 \%\left(10 / 54\right.$, 角田 $\left.5^{12)}\right), 1.8 \%(11 / 600$, 柳田 $5^{8)}$ ) と報告されて和り，われわれは $7 \%(15 / 210)$ であ った. 発生頻度は一定しないが，受診後頻回の聴力検査 が施行されれば今後さらに症例数が増えると思われる。

\section{2 . 報告例の概要}

本症例は特異な臨床経過をとるため, 各症例について 詳細な検討が行われている. 過去の報告例を引用しなが ら, 症例の概要を考察してみたい.

われわれの症例では, 男女比は男:女 $=5: 10$ で女性 に多くみられた. 従来の報告例では特に性差は一定して いない，発症年齢をみると，20歳代以上で特に 40 歳から 50 歳に多く平均年齢は41歳で, 従来の報告とほぼ一致し ていた. 最近の突発性難聴の発症年齢は50から60歳代に ピークをもつと言われて拈り ${ }^{14)}$ 若干年齢層が若いよう である。また少数ではあるが 10 歳代の症例報告もあり ${ }^{10)}$ 興味深い.

家族歴，既往歴について今までの報告で特記すべき記 載は少なく，われわれの症例でも同様であった．合併症 で糖尿病が 2 例みられた。誘因の報告は感冒, 過労など が挙げられている3)。われわれの症例では明らかな誘因 は認めなかった。

\section{3 . 難聴進行の状況}

1) 初診時の聴力所見

初診時の難聴聴力型をみると, 寺山ら ${ }^{2)}$ は䆍型と水平 型, 柳田 ${ }^{8)}$ は水平型之高音漸傾型, 立木ら ${ }^{11)}$ は高音漸 傾型の頻度が高いと述べているが，われわれの症例では
高音漸傾型が多かった．その他に低音部障害型や谷型な どもあり, 本症例に特徽的な聴力型はみられなかった。 また難聴の程度も様々であり, 一定の傾向はみられなか った.

\section{2 ) 難聴進行の周波数域}

難聴進行がどの周波数域で生じているかを検討するた めに初診時と悪化時の聴力図を比較してみると, 柳田 ら8) は高音域に較べて低音域になる程聴力低下の幅は大 きく, 初診時高音障害型のものは特に低音域の低下が著 明となり, 水平型や壟型となるものが多いと報告してい る. 前述の如く, 初診時聴力型は高音障害型のみではな く水平型, 低音障害型あるいは谷型もあるので, 立木 ら11) は難聴進行を悪化周波数域によって低音域型, 低 中音域型, 高音域型, 全音域型と 4 型に分類した. そし て低中音域型と全音域型が多く，高音域型は少ないと述 べている.われわれもこの分類に準じて症例を検討する と低中音域型と全音域型が多いようであったが，高音域 の難聴進行症例はみられなかった。

3 ）難聴進行停止までの期間

一度進行の始まった難㯖がいつ停止するかはわれわれ 臨床家にとって重大な関心事であり, 従来の報告例でも 詳細に記載されている. 難聴進行の停止するまでの期間 は発症後, 第 2 病日より第10病日までの幅の広い報告も あるが12)，多くの報告では第 4 病日から第 8 病日であり 1 週間前後と考光られる.われわれの症例も従来の報 告244771113) とほぼ一致する.

\section{4 ）難聴進行の状況}

難聴が進行して停止, すなわち最悪の難聴に至るまで の経過をみるため経時的に聴力を観察した。そその結果, 難聴進行は 3 型に分類することが出来た. 比較的に急速 に難聴が進行する型 ( I 型) と緩徐に進行する型 (II 型)の 両者を比較すると I 型は進行開始時の難聴の程度は比較 的軽度であるのに対して, II 型は 1 例(症例 2 )を除き難 聴の程度は高度であった。 そして難聴進行停止が発症後 1 週間といら一定期間であれば I 型の難聴進行曲線は急 速となり，II型のそれは緩徐となるのは当然であり, 難 聴進行の病態は I 型, II 型と共に大きな差異はないと想 像される.一方もら 1 つの型は難聴が発症した後一時 ( 1 日から 3 日間)安定した後に難聴が進行し, 1 週間前後 で進行が停止するものである(III型)，吕型の患者は問診 で難聴の進行を自覚しているものが多いことから，この 安定期は存在するものと思われた. しかしこの安定期を 
どの様に解釈するかは現在の所考えを持ち合わせていな い. 立木ら ${ }^{11)}$ は難聴進行を分析し治療開始後, 一旦聴 力が改善したあと再び悪化するものと, 治療開始後徐々 に悪化するものと $2 つ の$ 型に大別されると述べている. 従って初期の治療に反応寸る群としない群の 2 つが存在 することは本症の病態が単一でないことを示唆する.

\section{5 ）難聴の予後}

われわれは難聴の予後判定を厚生省特定疾患急性高度 難聴調查研究班の聴力回復判定基準によって行った.た だし，この場合最悪時の聴力と固定時のそれを比較した． われわれの症例では表 1 亿示す如く比較的良好であった。 柳田ら ${ }^{8)}$ は40例中, 治瘉と著明回復が33例と報告し, 寺 山ら ${ }^{6)}$ は治癒と著明回復が $80 \%$ であったとして，いずれ も予後良好と述べている. しかし治癒と著明回復例が50 \%といら報告 ${ }^{12)}$ や予後不良の報告4) もあり予後の成績は 一定していない。

4. 発症原因, その他

従来から症例の詳細な分析と検討が行われてきたが， 発症後の難聴進行の原因を説明するよらな有力な説はな い. 本症を初めて記載した寺山ら ${ }^{1)}$ の症例ではステロイ ド投与後難聴が悪化したことから，ステロイドによるウ イルス性内耳病変の悪化を疑っている.われわれの症例 では難聴進行後もさらに続けてステロイド剤を投与した が最終的には聴力著明回復例が多かったことより, 難聴 進行にはステロイドの影響は少ないと思われた。同様な 見解も報告されている78)10).

神崎4) は自験例 11 症例の分析から, 難聴の進行の原因 として(1)自然経過(2)イルス性内耳病変の悪化(3)循環障 害による病変の悪化(4)膜迷路 (あるいは内耳空) 破裂によ るものの 4 つの仮説を提唱している. われわれの症例で は, 血清ウイルス抗体測定で抗体価が上昇し, ウイルス 性病変を積極的に疑わせる症例は存在しなかった。 また 循環障害説に対しては臨床的に内耳病変を証明する検査 は確立されておらず，これを立証することは現状では困 難である. 膜迷路破裂説は，その診断基準に照合してみ ると，われわれの症例では外リンパ㾇を思わせるものは みられなかった。

以上のことから, 本症の発症原因として自然経過説が 最も有力と思われる. 突発性難聴の突発とは文字ど扣り, 短時間に高度の難聴を生じるものであるが，欧米諸国で は Byl15) や Mattox ら ${ }^{16)}$ は12時間以内に難聴が完成され るものを突発性難聴と診断している。また難聴発症から
数日以内に難聴が最悪になる症例もその延長上にあるも のとして, 柳田ら 2) はこれを slow type の突発性難聴と 考えている. 一方, 寺山ら ${ }^{6)}$ は発症してから 3 日以内で 難聴が最悪になる症例を急性進行性感音難聴として笑発 性難聴とは異なった型の急性感音難聴で, 独立疾患に分 類している。一方, 立木 ${ }^{17)}$ は緩徐形成型突発性難聴の 名称を与えている. 突発性難聴の第 1 の特徵は高度の難 聴が突発性に形成されることであって, 緩徐に難聴が形 成されるものを突発性難聴に含めてよいのかは問題であ るが, 発症後の難聴の進行以外は, 通常の突発性難聴と 同様の臨床像を示すものであるので, 非定型的な突発性 難聴の 1 つ考えられる. 突発性難聴自体が原因不明で あり独立疾患とは考兄られない現状では，この様な非定 型的な突発性難聴をも詳細に分析して,さらに細かく分 類することは突発性難聴の原因解明に結びつくと考兄ら れる.この点で今回われわれの経験した slow type ある いは緩徐形成型突発性難聴のなかでも難聴進行の周波数 域が異なったり，また難聴進行の様式も 3 つの型に分類 出来るなどから，この疾患も単一でないことが想像され る.

\section{結 語}

突発性に発症した難聴がさらに進行する15症例を経験 したので，その臨床像を供覧し従来の報告文献を引用し ながら若干の考察を行った。

1 。経験した症例は男性 5 例，女性 10 例，平均年齢 41 歳であった.

2. 発症後難聴がさらに進行して最悪になるのは 1 週 間前後であった。

3. 難聴が進行する周波数域は全音域, 低音域, 中音 域，低中音域であり，後者の症例が多かった．

4. 難聴進行の状況を経時的にみると，急速に進行す るもの( I 型), 緩徐に進行するもの (II型)，1〜3 日の 安定期の後進行するもの (正型)の 3 つの型がみられた.

以上の臨床所見, 聴力検查所見につき文献を引用しな がら若干の考察を行った.

\section{参考文献}

1) 寺山吉彦, 中村興治, 山地誠一, 他 : 感音難聴に対するス テロイド療法の再検討. 耳喉 $48: 1011 \sim 1017,1976$.

2 ) 柳田則之, 村橋けい子, 三宅 弘: slow type の Sudden deafness に関する検討. Audiology $20 ： 671 \sim 672,1977$. 
3 ) 神崎 壬, 大内利昭, 磯貝一豊 : 突発性難聴治療中の悪化 例について. 臨床耳科 8:206〜207, 1981.

4 ）神崎 不: 突発性難聴治療中の悪化例について. 厚生省特 定疾患特発性の感音難聴調査研究班 昭和55年度研究報告 書. 146 150頁, 1981.

5 ) 大橋正実, 寺山吉彦, 山川宗位, 他 : 発症後更に悪化した 突発性難聴. 日耳鼻 $84: 1189,1981$.

6 ) 寺山吉彦, 大橋正実, 松島純一, 他 : 急速進行性感音難聴 (急速性難聴)の検討. 耳鼻 $28: 840 \sim 844,1982$.

7 ) 南 吉昇 : 治療開始後にも聴力悪化を示した突発性難聴. 耳喉 $54: 377 \sim 383,1982$.

8 ）柳田則之, 鈴木康之, 村橋けい子, 他 : 初診後も聴力が悪 化した突発性難聴. 耳喉 $55: 581 〜 585,1983$.

9 ) 寺山吉彦, 松島純一, 林 光夫, 他 : 発症後聴力が悪化し た眩暈を伴 突発性難聴. 急性高度難聴調査研究班 昭和 60 年度研究業績報告書. 101 105頁, 1986 .

10）平出文久, 栫 博幸, 石田 孝: 突発性難聴と診断され聴 力悪化を示した症例. 耳鼻臨床 $83: 701 〜 707,1990$.

11）立木 孝, 村井和夫, 宾戸 潔, 他 : 初診後も聴力悪化を 認めた突発性難聴症例についての検討. 急性高度難聴調查
研究班 平成 3 年度研究業績報告書. 69 72頁, 1992 .

12）角田保雄, 大河内幸男, 大谷 蟋 : 初診後も聴力が変動覀 した突発性難聴症例。耳鼻臨床 補68：88～92, 1993.

13）吉田晋也, 池田 稔, 冨田 寛: 突発性難聴での聴力悪化 症例の検討. Otol Jpn $5:$ 434, 1995.

14）柳田則之 : 突発性難聴の現状 一疫学・治療・予後を中心 に一. 耳展 $38:$ 401 412, 1995.

15) Byl FM : Seventy-six cases of presumed sudden hearing loss occurring in 1973 ; prognosis and incidence. Laryngoscope $87: 817 \sim 825,1977$.

16) Mattox DE and Simmons FB : Natural history of sudden sensorineural hearing loss. Ann Otol $86: 463 \sim 480,1977$.

17）立木 孝 : 非定型的突発性難聴. 新難聴の診断と治療. 107 112頁, 中外医学社, 東京, 1986.

$\left(\begin{array}{l}\text { 原稿受付: 平成 } 8 \text { 年 } 1 \text { 月 } 4 \text { 日 } \\ \text { 原稿採択 : 平成 } 8 \text { 年 } 3 \text { 月 } 6 \text { 日 } \\ \text { 別刷請求先 : 本間利生 } \\ \text { 干 } 350 \text { 川越市鴨田辻道町 } 1981 \\ \text { 埼玉医科大学総合医療センター耳鼻咽喉科 }\end{array}\right)$

